\title{
Effect of twinning and stillbirth on the shape of lactation curve in Holstein dairy cows of Iran
}

\author{
Hadi Atashi', Mohammad Javad Zamiri' and Mohammad Bagher Sayyadnejad ${ }^{2}$ \\ ${ }^{1}$ Department of Animal Science, College of Agriculture, Shiraz University, Shiraz, Iran, ${ }^{2}$ Animal Breeding Center of Iran, \\ Karaj, Iran
}

\begin{abstract}
The aims of this study were to estimate the effects of twinning and stillbirth on the lactation curve traits in Holstein cows in Iran. Data from March 2000 to April 2009 comprising of 862109 test-day milk records corresponding to 115805 lactations of 58756 cows in 27 herds were used. The lowest peak and total lactation yield but the highest days in milk (DIM) until peak yield, persistency and cumulative milk yield from calving up to DIM at peak production were found during the first lactation $(P<0.05)$. Consequential effects of stillbirth and twinning on lactation curve traits, except for the factor associated with the downward slope of the curve, were significant $(P<0.05)$. Stillbirth affected the 100-d, 200-d and 305-d milk yields. Cows with stillborn calves had longer days to peak yield and higher persistency, but lower peak yield, than those with live calves $(P<0.05)$. Number of days to peak yield, the persistency and total lactation yield from calving up to peak of lactation were higher for twin birth than for single birth calvings $(P<0.05)$. The estimated correlation between peak yield and lactation yield was high (68\%) indicating that peak yield is very important in determining the lactation yield.
\end{abstract}

Keywords: stillbirth, lactation curve, incomplete gamma function, Holstein cow

\section{Introduction}

Stillbirth, defined as the death of a calf just prior to, during, or within 24 to $48 \mathrm{~h}$ of parturition, is a major issue in dairy cow management. Increased frequency of stillbirth during last decades has been reported in several countries (Meyer et al. 2000, Hansen et al. 2004, Berry et al. 2007, Bicalho et al. 2008). Stillbirth has considerable effects on the dairy industry through reduced number of calves, reduced lactation performance, increased risk of developing metritis and retained placenta, longer rebreeding intervals and increased hazard of involuntary culling (Mangurkar et al. 1984, Correa et al. 1993, Chassagne et al. 1999, Meyer et al. 2000, Meyer et al. 2001, Maizon et al. 2004, Berry et al. 2007, Bicalho et al. 2007, Bicalho et al. 2008).

To our knowledge, there is no scientific report on the effects of twinning and stillbirth on the shape of lactation curve. The objectives of this study were to estimate the effects of stillbirth and twinning on the shape of lactation curve, and on partial and 305-d lactation performance in Holstein dairy cows in Iran. 


\section{Materials and methods}

Data, lactation curve model fit and traits definition

Data from March 2000 to April 2009 comprising of 862109 test-day milk records corresponding to 115805 lactations of 58756 cows in 27 dairy herds collected by the Animal Breeding Center of Iran were used. Edits were on the number of test day records per cow $(>4)$, lactation length ( $\leq 320 \mathrm{~d})$, and days in milk (DIM) at which first test day was recorded $(\geq 5)$.

The herds were purebred Holsteins, managed under conditions similar to most developed countries and were under official performance and pedigree recording. The main ingredients of the total mixed ration consisted of corn silage, alfalfa hay, cottonseeds, cotton seed meal, barley grains, canola meal, wheat bran, fat powder, beet pulp, and feed additives.

To describe the lactation curve, the incomplete gamma function proposed by Wood (1967) was used. The function is as follows:

$$
y_{t}=a t^{b} e^{-c t}
$$

where $y_{t}$ is the daily milk yield in DIM $t$, the variable $t$ represents the length of time since calving, $e$ is the Neper number, $a$ is a parameter to represent yield at the beginning of the lactation, $b$ and $c$ are factors associated with upward and downward slopes of the curve, respectively. The incomplete gamma function was transformed logarithmically into a linear form as:

$$
\ln (y)=\ln (a)+b[\ln (t)]-c t
$$

and was fitted to monthly lactation yield records using a program written in Visual Basic 6 (Microsoft, Redmond, WA, USA). The DIM at peak production was defined as:

$$
T_{\max }=\left(\frac{b}{c}\right)
$$

expected maximum yield was calculated as:

$$
y_{\max }=a\left(\frac{b}{c}\right)^{b} e^{-b}
$$

persistency was calculated as:

$$
s=-(b+1) \ln (c)
$$

and finally, total yield from the calving up to days 100,200 , and 305 , and DIM at peak production (FCTP) was calculated as:

$$
y=a \int_{1}^{n} t^{b} e^{-c t} d n
$$

where $n=D I M$ of $100,200,305$, and DIM at peak production.

Stillbirth was defined as the death of a calf occurring just prior to, during, or within 24 to $48 \mathrm{~h}$ of parturition. When a calf was born alive as a singleton or when both calves were born alive in twin births, stillbirth was coded »D0《 otherwise; stillbirth was coded »D1《. The combination of calf sex and birth number (single vs. double) was shown as SST and coded as SM for male, SF for female in singleton births, and TWIN for male pairs, female pairs and mixed-sex pairs in twin births. Data on parity number were classified into five categories, parity $1,2,3,4$, and $\geq 5$. 


\section{Statistical analysis}

The effects of stillbirth and twinning on the parameters describing the lactation curve as well as partial and 305-d lactation performance, were determined using multiple regression mixed models in MIXED procedure of SAS 9.1 (SAS Institute Inc., Cary, NC, USA) through inclusion of stillbirth and twinning, effect of herd, calving year, and calving season combination (HYS), covariate effect of age of first calving (FCA), covariate effect of DIM at first test-day record, and random effect of dam's father. The Pearson's correlation among the lactation curve traits were estimated using PROC CORR of SAS 9.1.

\section{Results}

\section{Effects of stillbirth and twinning on the shape of lactation curve}

A typical lactation curve has positive $a, b$, and c parameters, characterised by an initial phase that increases to a maximum and is followed by a declining phase. Lactation curve with negative $a$, b or c parameters is considered atypical. In this study, $25.61 \%$ of all lactations were atypical and excluded from analysis. The squared multiple correlation coefficient $\left(R^{2}\right)$ of the log-transformed gamma function varied from $61.06( \pm 0.35)$ for the first parity to 79.05 $( \pm 0.40)$ for parity $\geq 5$. Of 86147 calving records, 95.03 and $4.97 \%$ had delivered live calves and stillborn calves, respectively. The incidence of stillbirth by herd ranged from 0.13 to $19.21 \%$. The overall twinning rate was $3.38 \%$, and the percentage of male calves among singletons was $51.54 \%$.

The potential consequential effect of stillbirth, interaction effect of calf gender and birth number, parity, FCA and DIM at the first test day recording on the lactation curve traits are presented in Table 1. The lowest peak and lactation yield but the highest DIM until peak yield, persistency and cumulative milk yield from calving up to DIM at peak production were found during first lactation $(P<0.05)$. First lactation cows produced lower $100-d, 200-d$ and 305-d milk and had flatter lactation curves than older cows (Table 1). Consequential effect of stillbirth and twinning on lactation curve traits except for factor associated with the downward slope of the curve (c) were significant $(P<0.05)$. Stillbirth parturition negatively affected the 100-d, 200-d and 305-d milk yields. Cows with stillbirth had higher DIM until peak yield and higher persistency but lower peak yield than cows delivering live calves $(P<0.05)$. Twinning resulted in lower $100-d, 200-d$ and $305-d$ milk yield $(P<0.05)$. DIM until peak yield, persistency, and lactation yield from calving up to DIM at peak production were higher for twin birth parturition than for single birth calvings $(P<0.05)$.

\section{Correlation among parameters of the lactation curve}

Phenotypic correlation coefficients between lactation curve traits are shown in Table 2. There was a high correlation between 305-d milk and peak yields (68\%), indicating that higher producing cows usually took longer than lower producing cows to reach peak production and require high peak yield and persistency. The larger correlation coefficient between peak yield and lactation yield (68\%) compared with the smaller correlation coefficient between persistencyand lactation yield (13\%) indicates that peakyield is more important in determining 


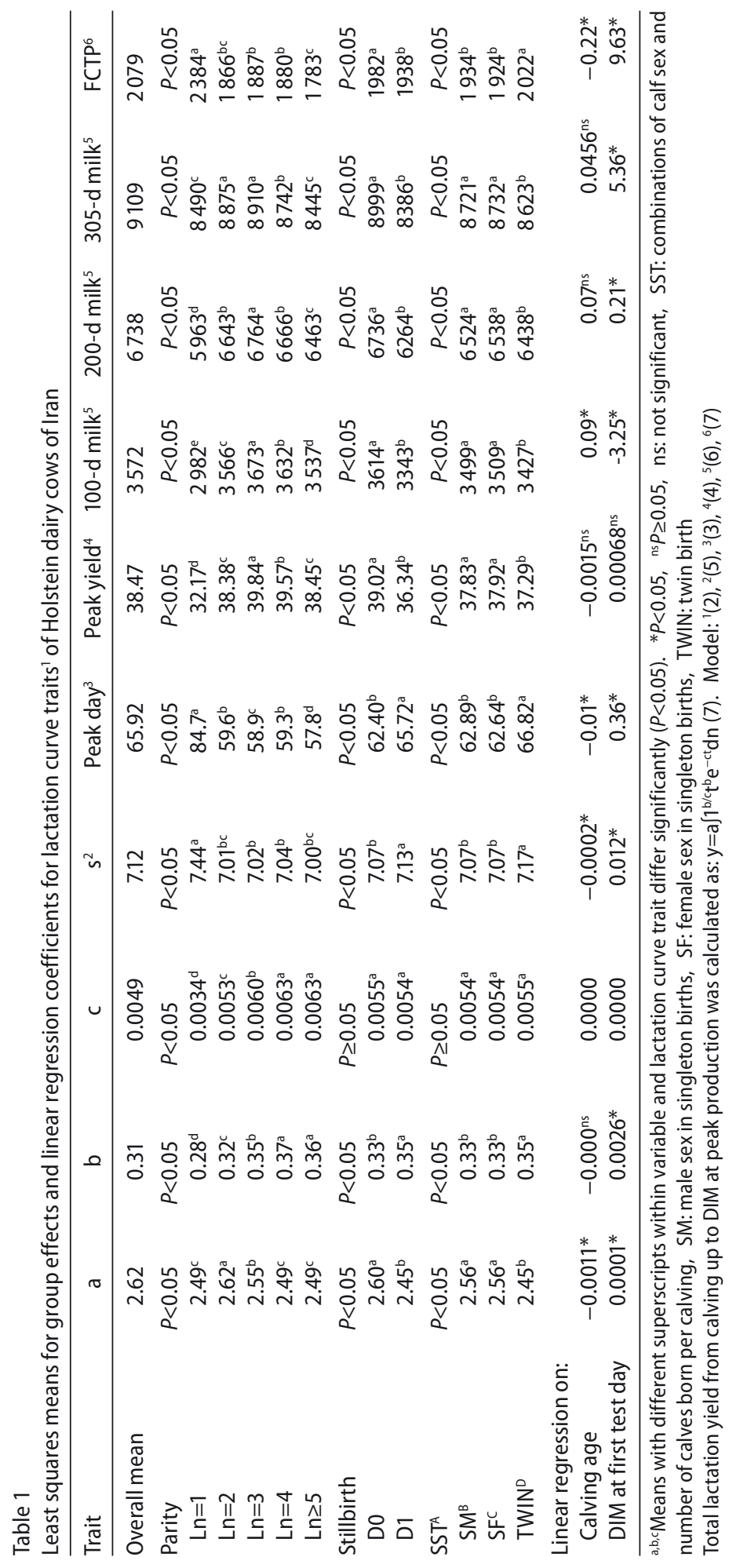


the lactation yield than persistency. The average 305- $d$ milk yield was increased by $173.5( \pm 0.8)$ and $11.34( \pm 0.23) \mathrm{kg}$ for every extra $\mathrm{kg}$ of milk at peak lactation and every extra day to reach at peak yield, respectively. The correlation coefficient between yield at the beginning of lactation, $a$, and factor associated with the upward slope of the curve, $b$, was negative (-94\%). Positive correlation (78\%) was found between factors associated with the upward and downward slopes of the curve ( $b$ and $c$ ). The correlation coefficient between DIM at peak yield and persistency was $84 \%$ (Table 2).

Table 2

Phenotypic correlations between lactation curve traits' of Holstein dairy cows of Iran

\begin{tabular}{|c|c|c|c|c|c|c|c|c|c|}
\hline Trait & $b$ & c & $s^{2}$ & Peak day ${ }^{3}$ & Peak yield 4 & $100-\mathrm{d}$ milk & 200-d milk ${ }^{5}$ & 305-d milk ${ }^{5}$ & FCTP 6 \\
\hline$a$ & $-0.94^{* *}$ & $-0.59^{* *}$ & $-0.78^{* *}$ & $-0.56^{* *}$ & $0.10^{* *}$ & $0.35^{* *}$ & $0.25^{* *}$ & $0.29 * *$ & $-0.43^{* *}$ \\
\hline$b$ & & $0.78^{* *}$ & $0.66^{* *}$ & $0.39 * *$ & $0.21^{* *}$ & $-0.04^{* *}$ & $-0.026^{* *}$ & $-0.16^{* *}$ & $0.38^{* *}$ \\
\hline c & & & $0.11^{* *}$ & $-0.14^{* *}$ & $0.33^{* *}$ & $0.14^{* *}$ & $-0.10^{* *}$ & $-0.37^{* *}$ & $-0.10^{* *}$ \\
\hline s & & & & $0.84^{* *}$ & $-0.10^{* *}$ & $-0.28^{* *}$ & $-0.006^{\mathrm{ns}}$ & $0.13^{* *}$ & $0.76^{* *}$ \\
\hline \multicolumn{2}{|c|}{ Peak day } & & & & $-0.20^{* *}$ & $-0.33^{* *}$ & $-0.01^{*}$ & $0.18^{* *}$ & $0.91^{* *}$ \\
\hline \multicolumn{2}{|c|}{ Peak yield } & & & & & $0.95^{* *}$ & $0.87^{* *}$ & $0.68^{* *}$ & $0.16^{* *}$ \\
\hline \multicolumn{2}{|c|}{ 100-d milk } & & & & & & $0.91^{* *}$ & $0.73^{* *}$ & $0.50^{* *}$ \\
\hline \multicolumn{2}{|c|}{ 200-d milk } & & & & & & & $0.94^{* *}$ & $0.42^{* *}$ \\
\hline \multicolumn{2}{|c|}{ 305-d milk } & & & & & & & & $0.36^{* *}$ \\
\hline
\end{tabular}

${ }^{*} P<0.05$, ${ }^{*} P<0.01,{ }^{n s} P \geq 0.05$, ns: not significant, Total lactation yield from calving up to DIM at peak production was calculated as: $y=a$ a $1 \mathrm{~b} / \mathrm{ctbe}-\mathrm{ctdn}(7)$. Model: ${ }^{1}(2),{ }^{2}(5),{ }^{3}(3),{ }^{4}(4),{ }^{5}(6),{ }^{6}(7)$

\section{Discussion}

In this study, $25.61 \%$ of all lactations were atypical (a, b or c with negative values) which is characterised by the absence of a lactation peak. Rekik et al. (2003) reported $15 \%$ to $42 \%$ atypical curves in dairy herds of Tunisia. Atashi et al. (2006) and Tekerli et al. (2000) reported $17.7 \%$ (of 36487 ) and $26.3 \%$ (of 1278 ) atypical curves in Holstein dairy cows of Iran and Turkey, respectively. Variability in the quantity and quality of ration as well as physiological and health problems related to harsh environmental conditions (heat in summer) may lead to atypical lactation curves (Rekik \& Gara 2004). Macciotta et al. (2006) considered the time from parturition to the first recorded test, as the most important factor affecting the incidence of atypical lactation curves. The squared multiple correlation coefficient of the logtransformed gamma function varied from $61.06( \pm 0.35)$ for first parity to $79.05( \pm 0.40)$ for parity $\geq 5$. Less accurate fitting of the lactation curve was associated with first lactation than with later lactations, which is in agreement with previous studies (Shanks et al. 1981, Tekerli et al. 2000). The lowest peak and lactation yields but the highest persistency was found during the first lactation. First parity cows also reached their peak of production later and tended to have flatter lactation curves than multiparous cows. Similar findings were reported earlier (Rao \& Sundaresan 1979, Singh \& Shukla 1985, Keown et al. 1986, Tekerli et al. 2000). Rao \& Sundaresan (1979) reported that the milk secretory tissue in primiparous animals takes longer to reach its peak activity than in multiparous animals. Stillbirth and twinning significantly affected lactation curve traits except for the parameter associated with the downward slope of the curve (c). The results showed that the DIM until peak yield, persistency and lactation yield from calving up to DIM at peak production was higher for 
twin birth than for single birth parturitions. The reported data on the effects of twin birth on subsequent performance are inconsistent. Kay (1978), and Bell \& Roberts (2007) reported no significant difference in lactation performance of cows delivering twins or singletons. Nielen et al. (1989) reported cows bearing twins produced an average of $103 \mathrm{~kg}$ more milk during the first $100 \mathrm{~d}$ of lactation compared with the cows bearing single calves, however no significant differences in milk production were found during the latter part of lactation. Such discrepancies may be the result of differences in management of twin-bearing cows during gestation and lactation. In the present work, DIM until peak yield was longer and the persistency was higher in cows with stillbirth. The least squares means of 305-d milk yield for cows with stillbirth were $8386.24( \pm 34.83)$ and $8999.18( \pm 22.43) \mathrm{kg}$ for cows with live birth. Therefore, a case of stillbirth reduced milk yield by $612.94( \pm 28.98) \mathrm{kg}$ per cow per lactation. Bicalho et al. (2008) found that mean 305-d milk yield for a cow with a stillborn calf was decreased by $323.3 \mathrm{~kg}$ per cow per lactation. Mangurkar et al. (1984) reported a milk loss from prenatal deaths of $100-400 \mathrm{~kg}$ of milk, $4-11.5 \mathrm{~kg}$ of fat, and $2.5-13 \mathrm{~kg}$ of protein. Berry et al. (2007) found that cows that had a stillborn calf produced $51.9 \mathrm{~kg}$ less milk during the first 60 days of lactation. Chassagne et al. (1999) reported a significant reduction in 305-d milk yield in cows with stillborn calf $(5582 \mathrm{~kg}$ ) than cows without $(6140 \mathrm{~kg})$.

Mammary cell proliferation starts in early gestation and rises exponentially until it reaches its maximum after parturition (Knight \& Wilde 1993). Mammary cell numbers start to decline, by apoptosis after parturition and this decline progresses until the end of lactation (Wilde et al. 1997, Pollott 2000). The increase in milk production during early lactation is largely due to the rate at which mammary cells become active (differentiated) and the decline in milk yield in later lactation is due to the rate of apoptosis (Pollott 2000). It could be concluded that mammary cell proliferation and differentiation are reduced in stillbirth and twin birth calvings and peak later than for live birth and single birth, but the rate of decrease in apoptosis is similar in stillbirth and live birth or twin birth or single birth calvings.

The observed relationships among main lactation curve traits agree with earlier findings (Keown et al. 1986, Tekerli et al. 2000, Rekik et al. 2003). The estimated correlation between peak yield and lactation yield (68\%) was higher than that between persistency and lactation yield (13\%) indicating that peak yield is more important in determining lactation yield than is persistency. Cows with the higher peak yield are likely to produce highest amount of milk. Therefore, producers should use peak yield as a management tool to monitor milk production performance of the herd. The significant correlations between 305- $\mathrm{d}$ milk yield and persistency showed that cows with higher persistency would be expected to have higher 305-d milk yield.

The strong negative correlation(-94\%) between milk yield at the beginning of the lactation (a) and factor associated with the upward slope of the curve (b) indicated that higher initial yield is associated with a lower rate of increase to peak yield. The positive correlations (78\%) between factors associated with the upward and downward slopes of the curve ( $b$ and $c$ ) implied that cows that peaked more rapidly also had a faster rate of decline after reaching their peak production. The increase in milk production during early lactation is largely due to the rate at which mammary cells become active and the decline in milk yield in later lactation is due to the rate of apoptosis in mammary cells (Pollott 2000). Therefore, the rate at which mammary cells become active and the rate of cell death may be positively 
correlated. Correlations between DIM at peak yield and persistency measures suggested that cows that reach peak yield later during lactation would have higher persistency.

\section{Acknowledgement}

This research was supported by The Center of Excellence for Studies on Reproduction of High-Producing Cows, School of Veterinary Science, Shiraz University, Iran. The co-operation of the Animal Breeding Center for providing the data is greatly appreciated.

\section{References}

Atashi H, Moradi Shahrbabak M, Abdolmohammadi A (2006) Study of some suggested measures of milk yield persistency and their relationships. Int J Agric Biol 8, 387-390

Bell MJ, Roberts DJ (2007) Effect of twinning on the feed intake, performance and health of dairy cows. Livest Sci 107, 274-281

Berry DP, Lee JM, Macdonald KA, Roche JR (2007) Body condition score and body weight effects on dystocia and stillbirths and consequent effects on postcalving performance. J Dairy Sci 90, 4201-4211

Bicalho RC, Galvão KN, Cheong SH, Gilbert RO, Warnick LD, Guard CL (2007) Effect of stillbirth on dam survival and reproduction performance in Holstein dairy cows. J Dairy Sci 90, 2797-2803

Bicalho RC, Galvão KN, Warnick LD, Guard CL (2008) Stillbirth parturition reduces milk production in Holstein cows. Prev Vet Med 84, 112-120

Chassagne M, Barnouin J, Chacornac JP (1999) Risk factors for stillbirth in Holstein heifers under field conditions in France: A prospective survey. Theriogenology 51, 1477-1488

Correa MT, Erb H, Scarlett J (1993) Path analysis of seven postpartum disorders of Holstein cows. J Dairy Sci 76, 1305-1312

Hansen M, Misztal I, Lund MS, Pedersen J, Christensen LG (2004) Undesired phenotypic and genetic trend for stillbirth in Danish Holsteins. J Dairy Sci 87, 1477-1486

Kay RM (1978) Changes in milk production, fertility, and calf mortality associated with retained placentae or the birth of twins. Vet Rec 102, 477-479

Keown JF, Everett RW, Empet NB, Wadell LH (1986) Lactation curves. J Dairy Sci 69, 769-781

Knight CH, Wilde CJ (1993) Mammary cell changes during pregnancy and lactation. Livest Prod Sci 35, 3-19

Macciotta NPP, Dimauro C, Catillo A, Coletta A, Cappio-Borlino A (2006) Factors affecting individual lactation curve shape in Italian river buffaloes. Livest Sci 104, 33-37

Maizon DO, Oltenacu PA, Groehn YT, Strawderman RL, Emanuelson U (2004) Effects of diseases on reproductive performance in Swedish Red and White dairy cattle. Prev Vet Med 66, 113-126

Mangurkar BR, Hayes JF, Moxley JE (1984) Effects of calving ease-calf survival on production and reproduction in Holsteins. J Dairy Sci 67, 1496-1509

Meyer CL, Berger PJ, Koehler KJ (2000) Interactions among factors affecting stillbirths in Holstein cattle in the United States. J Dairy Sci 83, 2657-2663

Meyer CL Berger PJ, Koehler KJ, Thompson JR, Sattler CG (2001) Phenotypic trends in incidence of stillbirth for Holsteins in the United States. J Dairy Sci 84, 515-523

Nielen M, Schukken YH, Scholl DT, Wilbrink HJ, Brand A (1989) Twinning in dairy cattle: A study of risk factors and effects. Theriogenology 32, 845-862

Pollott GE (2000) A biological approach to lactation curve analysis for milk yield. J Dairy Sci 83, 2448-2458

Rao MK, Sundaresan D (1979) Influence of environment and heredity on the shape of lactation curves in Sahiwal cows. J Agric Sci 92, 393-401 
Rekik B, Ben Gara A (2004) Factors affecting the occurrence of atypical lactations for Holstein-Friesian cows. Livest Prod Sci 87, 245-250

Rekik B, Ben Gara A, Ben Hamouda M, Hammami H (2003) Fitting lactation curves of dairy cattle in different types of herds in Tunisia. Livest Prod Sci 83, 309-315

Shanks RD, Berger PJ, Freeman AE, Dickinson FN (1981) Genetic aspects of lactation curves. J Dairy Sci 64, $1852-1860$

Singh J, Shukla KP (1985) Factors affecting persistency of milk production in Gir cattle. Indian Vet J 62, 888-894

Tekerli M, Akinci Z, Dogan I, Akcan AM (2000) Factors affecting the shape of lactation curve of Holstein cows from the Balikesir Province of Turkey. J Dairy Sci 83, 1381-1386

Wilde CJ, Quarrie LH, Tonner E, Flint DJ, Peaker M (1997) Mammary apoptosis. Livest Prod Sci 50, 29-37

Wood PDP (1967) Algebraic model of the lactation curve in cattle. Nature 216, 164-165

Received 11 April 2011, accepted 10 January 2012.

Corresponding author:

Hadi Atashi

email: atashi@shirazu.ac.ir

Department of Animal Science, College of Agriculture, Shiraz University, Shiraz, Iran 